\title{
Are platform workers really their own boss?
}

Written by: Clara Young, OECD Observer

Last update: 29 January 2020

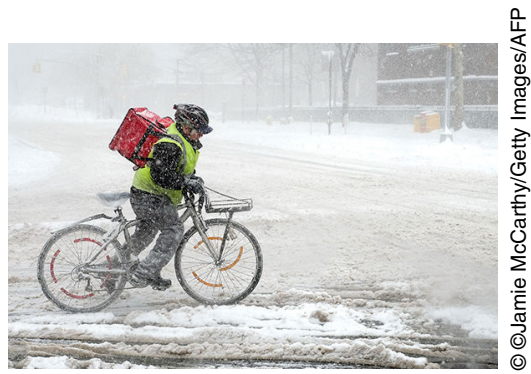

Are platform workers really their own boss I Picture for Are platform workers really their own boss?

\section{Smart communications technology has enabled people to hire themselves out as independently contracting workers in everything from taxi drives to video producers and gardeners. But what is the status of these workers, and what are the challenges of the so-called gig economy?}

When Tybalt Mooney graduated from high school, he looked for a job to help pay for college. He signed up with a bicycle courier service. It delivered not just takeout food, but anything from foot creams to fast-food burgers and cups of coffee. Tybalt had to have his own bike and a $4 \mathrm{G}$ smartphone onto which he could download the company app and log in to whenever he wanted to pick up a few hours of work. Despite working for the courier service, he nevertheless had to get his papers as a self-employed worker through which he paid for his own social security. What did the company supply him with? A big delivery bag, the app and shifts.

"I could get up whenever I wanted and work for how ever long I wanted," says Tybalt. "But if I had been dependent on that job and on that income, I would be in a pretty sorry place because you get paid little, it's hard, and you're on your own. If I had had an accident, I wouldn't have got anything. I don't have any paid leave. When you're biking, you nod when you see another courier, but you're never going to stop. Those people don't protest, don't march, they don't know each other. Your only colleagues are your cellphone and your bicycle." 
This is one insider's view of the gig economy. Smart communications technology has enabled people to hire themselves out as independently contracting video producers, food deliverers, taxi drivers and even plumbers or gardeners through online platforms that anyone can access from their phone. Uber cars and mealdelivery firm Deliveroo stand out among a growing myriad of online firms. Because they are their own boss, these gig or platform workers have total flexibility.

"It's good for people who have been structurally excluded from the labour market. Like people with disabilities or who have been out of a job for too long," says Jeremias Prassl, an associate professor at Oxford University and author of Humans as a Service. The Promise and Perils of Work in the Gig Economy. "They go on Upwork and suddenly they are back in the labour market."

The downside is the lack of job security and protection like sick pay and unemployment insurance. This is a problem, since the pay itself sometimes does not compensate, as Tybalt says. Still, it is handy for workers and clients. Some services can be done regardless of where you live, like translating or accounting, and some platforms crowd-source workers from all over the globe, leading to fierce competition. As Tybalt wonders, is this gig really his future?

And here's another question: are platforms workers really "their own boss"? Truly independent contractors negotiate their own rates and contracts on the free market; housecleaners from Handy.com, for instance, do not. They are dependent on the platform software for connecting them with clients and, often, setting fees, the latter of which is governed by opaque algorithms that neither customer nor service worker have control over. Gig workers are too often in a limbo where they are neither true independent contractors nor employees. This is not always the case: a 2016 UK employment tribunal, reported in The Guardian, ruled that Uber drivers were workers and not independent contractors, and should be paid a living wage. However, there are other ongoing cases, in construction for instance, where status remains unclear (see www.out-law.com). In Canada, platform workers are in a category of their own, called dependent contractors.

This will have to be sorted out if only because gig workers, though still small in number, are growing. A recent briefing paper on employment status in the UK estimated that up to 1.3 million people worked in the platform economy in 2017. A McKinsey Global Institute report estimates that there will be about 72 million individuals working full-time around the world via platforms by 2025. If these workers continue to be classified as independent contractors, they risk losing out on security, benefits and decent pay and working conditions. But it could also upend the labour market as we know it today. If employers are not bound by social security contributions, taxes, workplace guarantees or legal and contract obligations beyond those of a specific task, companies will lower their overhead costs and shift from salaried employees to gig workers. 
One reform being aired is to make benefits portable. Rather than tying social insurance and protection to work contracts, they would belong to the individual regardless of their place of work or employer. Workers could accumulate rights to training or other benefit in personal accounts and draw on these when needed.

Another way to untie benefits from employers and workplaces is to make benefits universal and fund them through tax revenue rather than contributions. This is how New Zealand funds its basic pension, for instance, which pays about $40 \%$ of average earnings to all retirees no matter their work records. Another model is universal basic income, which takes the form of a cash payment to all citizens. Still in experimental stage in Ontario, Kenya and Scotland, the idea has lost favour in Finland, where it had been tested, albeit in a limited way, since 2017.

There is also the difficulty of unemployment insurance. The fluctuating earnings of the self-employed are difficult to track. And as with the self-employed, how do you monitor a gig worker's job search efforts? How can you be sure that a gig worker is genuinely unemployed and not deliberately rejecting jobs in order to get benefits? Unemployment benefits for the self-employed are an extraordinarily tricky issue, and though France has just introduced them, they are in 20 out of 34 OECD countries.

Policymakers need to find answers because the isolated nature of gig work makes it difficult for them to organise, let alone mobilise, for reform. Even if they could, the legal status of gig workers as independent contractors or self-employed may be a barrier, since anti-trust and anti-competition laws prohibit them from collective action. This was demonstrated in 2018 when a 2015 ordinance from the city of Seattle creating collective bargaining rights for for-hire drivers was overturned in a court of appeal.

The platform economy enables people to work who couldn't before. Gig workers can craft their worktime around other time-consuming obligations. They can also connect in to work done remotely, doing jobs that aren't available to them locally. The freedom and employment gig work offers is exciting but it has blurred old labour classifications. This is what disruption does. When basic rights are flouted, corners will be cut and standards will drop, in which case employees and employers, as well as customers, will all lose. The legal status of gig workers needs to be pinned down. Our car rides, skilled plumbing and our food deliveries from the likes of Tybalt may soon depend on it.

On 7 November 2018 the OECD hosted a conference "Policy responses to new forms of work". Visit: www.oecd.org/employment/future-of-work/

COECD Observer No 317, Q1 2019

\section{References}

Johnston, Hannah and Land-Kazlauskas, Chris, "Organizing on-demand: Representation, voice and collective bargaining in the gig economy", ILO, 
Geneva, 2018 at https://www.ilo.org/wcmsp5/groups/public/---ed_protect/--protrav/---travail/documents/publication/wcms_624286.pdf https:// www.ilo.org/wcmsp5/groups/public/---ed_protect/---protrav/---travail/ documents/publication/wcms_624286.pdf

Cherry, Miriam A. and Aloisi, Antonio, 'Dependent Contractors' in the Gig Economy: A Comparative Approach, 2016. Available at SSRN: http://dx.doi.org/ https://ssrn.com/abstract=2847869 or http://dx.doi.org/10.2139/ssrn.2847869

NFIB (2018), "Federal Court Rules that Seattle's “Uber Ordinance” Violates Federal Antitrust Law", see https://www.nfib.com/ see https:/www.nfib.com/ 